\title{
Plagiarism: Who is responsible author or the journal editors?
}

\author{
Banerjee I1 , Roy B ${ }^{2}$, Sathian B ${ }^{3}$, Banerjee I ${ }^{4}$, Saha $\mathrm{A}^{5}$
}

${ }^{1}$ Lecturer, Department of Pharmacology, Manipal College of Medical Sciences, Pokhara, Nepal

${ }^{2}$ Assistant Professor, Department of Physiology, Manipal College of Medical Sciences, Pokhara, Nepal

${ }^{3}$ Assistant Professor, Department of Community Medicine, Manipal College of Medical Sciences, Pokhara,

Nepal

${ }^{4}$ Post Doctorate Trainee, SMS Medical College, Jaipur, India

5Professor and Head, Department of Pharmacology, Manipal College of Medical Sciences, Pokhara, Nepal

Chief Editor

Dr. Jayadevan $S$

Technical Editor

Dr. Nishida Chandrasekharan

Formatting Editor

Dr. Nishida Chandrasekharan

This title

is indexed

in SciVerse

Scopus

Improving research

results through

results through
analytical power

\section{Letter to the Editor}

\author{
Corresponding Author: \\ Dr. I. Banerjee MD \\ Lecturer, Department of Pharmacology, \\ Manipal College of Medical Sciences,Pokhara,Nepal \\ E-mail:indrajit18@gmail.com
}

Dear Sir,

Plagiarism is a stealing of other's words, language or ideas and then calls the work his own. It is reflected as an unethical practice which has always remains alarming in medical literature ${ }^{1-3}$.

I am writing in context to an article recently been published in the Journal of Drug Delivery and Therapeutics, Volume 3, Issue 4, July-August 2013 entitled "Medications For Anxiety: A Drug Utilization Study In Psychiatry Outpatients From A
Tertiary Care Centre Of Eastern India ${ }^{4}$. http://jddtonline.info/index.php/jddt/article/view/574

I was very shocked to see that the above article is plagiarized from one of my paper which is the most popular article 53475 views till 21st July 2013 in NJE, "Medications for Anxiety: A Drug Utilization Study In Psychiatry Inpatients From A Tertiary Care Centre of Western Nepal, ${ }^{\prime 5}$ published in Nepal Journal of Epidemiology on September 2011. http://nepjol.info/index.php/NJE/article/view/5753

\section{Critical Appraisal of the Plagiarized article:}

Abstract: Copied $100 \%$ from my paper, most interestingly the authors even forgot to modify place of the study. The authors have even copied Manipal Teaching Hospital in the place of study instead of Burdwan Medical College, West Bengal. Manipal Teaching Hospital is situated in Nepal and not in West Bengal, India.

In the abstract in the background section of the study it is mentioned that the study was undertaken in inpatients but the title it is mentioned as A Drug Utilization study in Psychiatry Outpatients from a tertiary care centre of 
Eastern India.

Introduction: Copied from my paper

Discussion: Subheadings are copied

a. Psychiatric Diseases: Paragraph is copied

b. Socio- Demographic Details and Anxiety: Paragraph is copied

c. Pharmacotherapy of Anxiety: Copied

Conclusion: Copied 100\% except one word (Full paragraph has been copied word to word). Only the drug name Alprazolam was replaced by Clonazepam.

References: The references are also copied from my paper. In one of the references even the date of accessing one of the article is similar to my paper. It was mentioned as (article accessed on 1st August 2011). According to the authors they have performed the study in between 1st October 2012 and 31st January 2013.

This is how a paper should be written? It is evident that the authors have done plagiarism of the NJE article. According to me both authors and the journal editors should be blamed for such an unethical act. The major fault lies with the authors. But it is the journal editor's duty to undergo plagiarism checking before sending the article for peer review which can reduce this practice in medical field in future.

\section{Acknowledgment}

I extend our heartfelt and cordial gratitude to Dr Akhilesh Chandra Jauhari, Professor, Department of Pharmacology, Manipal College of Medical sciences, Nepal.

\section{References}

1.Vogelsang J. Plagiarism--an act of stealing. J Perianesth Nurs. 1997 Dec;12(6):422-5.

2. Harper MG.. High tech cheating. Nurse Educ Today. 2006 Dec;26(8):672-9 2.

3. Skandalakis JE, Mirilas P. Plagiarism. Arch Surg. 2004 Sep;139(9):1022-4.

4. Ghosh S, Bhattacharyya S, Bhattacharya A. Medications for Anxiety: A Drug Utilization Study In Psychiatry. Journal of Drug Delivery \& Therapeutics; 2013, 3(4), 79-84 .

5. Banerjee I, Roy B, Sathian B, Banerjee I, Kumar SS, Saha A: Medications for Anxiety: A Drug utilization study in Psychiatry Inpatients from a Tertiary Care Centre of Western Nepal. Nepal Journal of Epidemiology 2010, 1(4):119-25.

\section{Article Information}

\section{Article history}

Received $29^{\text {th }}$ August 2013

Received in revised form $3^{\text {rd }}$ September 2013

Accepted $23^{\text {rd }}$ September 2013 